\title{
Correction to: Mining a stroke knowledge graph from literature
}

Xi Yang ${ }^{1,2,3}$, Chengkun Wu${ }^{2}$, Goran Nenadic ${ }^{3 *}$, Wei Wang ${ }^{1}$ and Kai Lu ${ }^{1}$

The original article can be found online at https://doi. org/10.1186/s12859-02104292-4.

\section{${ }^{*}$ Correspondence:}

g.nenadic@manchester.ac.uk

${ }^{3}$ Department

of Computer Science,

University of Manchester,

Manchester M13 9PL, UK

Full list of author information is available at the end of the article

\section{Correction to: BMC Bioinformatics (2021) 22:387 \\ https://doi.org/10.1186/s12859-021-04292-4}

Following publication of the supplement article [1], the authors identified an error in the equal contributors.

After a sincere and thorough discussion among the authors it was decided that Chengkun Wu should not be listed as the 1st co-author. All authors agreed that Xi Yang should be the only 1st author of the paper.

The author group has been updated above and the original article [1] has been corrected.

\section{Author details \\ ${ }^{1}$ College of Computer, National University of Defence Technology, Changsha 410073, China. ${ }^{2}$ State Key Laboratory of High-Performance Computing, National University of Defence Technology, Changsha 410073, China. ${ }^{3}$ Department of Computer Science, University of Manchester, Manchester M13 9PL, UK.}

Published online: 08 December 2021

\author{
Reference \\ 1. Yang X, Wu C, Nenadic G, et al. Mining a stroke knowledge graph from literature. BMC Bioinformatics. 2021;22:387. \\ https://doi.org/10.1186/s12859-021-04292-4.
}

\section{Publisher's Note}

Springer Nature remains neutral with regard to jurisdictional claims in published maps and institutional affiliations. author(s) and the source, provide a link to the Creative Commons licence, and indicate if changes were made. The images or other third party material in this article are included in the article's Creative Commons licence, unless indicated otherwise in a credit line to the material. If material is not included in the article's Creative Commons licence and your intended use is not permitted by statutory regulation or exceeds the permitted use, you will need to obtain permission directly from the copyright holder. To view a copy of this licence, visit http:// creativecommons.org/licenses/by/4.0/. The Creative Commons Public Domain Dedication waiver (http://creativecommons.org/publicdomain/zero/1.0/) applies to the data made available in this article, unless otherwise stated in a credit line to the data. 